\title{
THE STATUS OF PARTHENIUM HYSTEROPHORUS AND ITS POTENTIAL MANAGEMENT
}

\author{
P.C. Bhowmik, D. Sarkar and N.T. Yaduraju* \\ Department of Plant, Soil and Insect Sciences \\ University of Massachusetts Amherst, MA 01003-7245, USA \\ *Indian Council of Agricultural Research, New Delhi, India
}

\begin{abstract}
Parthenium hysterophorus L. (Ragweed parthenium) is an aggressive herbaceous weed of tropical and subtropical habitats. This species is native to Gulf of Mexico and central South America and has become widespread in North America, South America, the Caribbean and many parts of Africa, Asia and Australia. Ragweed parthenium is currently identified as an invasive species in several countries, including India and Nepal. Parthenium is primarily found in the wastelands, vacant areas, community parks, roadsides and even invades agricultural fields. It is a major weed in crop and pasture areas in India and Australia. This weed species threatens human and animal health by causing allergic contact dermatitis, hay fever, and respiratory problems in sensitive humans and animals. Parthenium adversely affects crop production, animal husbandry and human health. This species is known to have several allelochemicals that may have ecological implications on species diversity in various habitats. Limited control practices are available for managing this species in various environments. Although it is a problem weed in Australia, India, Nepal and other Asian subcontinents, it may become more prominent in other parts of the world in the near future. Global strategies in relation to identification, early detection, spread and management must be developed for its future invasion.
\end{abstract}

Key words: Invasive species, biological control, Parthenium hysterophorus, congress grass, carrot grass, false ragweed, kanike ghas, ragweed parthenium

\section{INTRODUCTION}

Ragweed parthenium (Parthenium hysterophorus L.), a member of Asteraceae family, is a prolific and aggressive herbaceous weed of tropical and subtropical environments. The word parthenium was derived from the Latin parthenice suggesting medicinal uses (Bailey 1960) and hysterophorus was derived from the Greek hystera (womb) and phoros (bearing), referring to the prolific seed habit of the plant (Parsons and Cuthbertson 1992). The weed is also commonly known as congress weed, star weed, carrot weed, white top, whitehead, feverfew, bitter weed, broom-bush, escobar amarga, false ragweed in different parts of the world. Although it is a problematic weed in Australia and in Indian subcontinent, but due to its rapid spreading it may become more prominent in other parts of the world in the near future (Evans 1997). This species was not listed in world's worst weed until 1977. However, within the last two decades it has become one of the seven most dreaded weeds of the world. Factors such as high fecundity, efficient seed dispersal, absence of natural predators, allelopathic impacts to the other plants, presence of anti-feedants and wide adaptability to varying soil and agro-climatic conditions have enabled this plant to invade a variety of natural environments. The weed is known to adversely affect crop production, animal husbandry, human health and biodiversity. Very few other weeds have such a wide ranging and potentially lethal impact on human affairs. The present review is an attempt to give an overall idea about the distribution, biology, management and future strategy of parthenium weed. 


\section{Origin and distribution}

Parthenium weed is native to Gulf of Mexico and central South America and has become widespread in North America, South America, the Caribbean and many parts of Africa, Asia and Australia (Bhowmik and Sarkar 2005, Navie et al. 1996). In U.S.A., it spreads from Florida to Texas, north of Massachusetts, Michigan, Illinois, Louisiana, Missouri and Kansas (Gleason and Cronquist 1963). It has been also reported from Baltimore, New Port News and Virginia. It is a major crop and pasture weed in India and Australia in particular, where it causes several detrimental effects. Parthenium was introduced in Africa, Asia and Oceania in cereal and grass seed shipments from U.S.A. during the 1950s. Two biotypes of Parthenium hysterophorus have established in Australia as a result of two different introductions from U.S.A. The first introduction occurred in south-east Queensland and the second in Central Queensland (Navie et. al.1996). In Australia, it has become widespread in grazing land from central Queensland to northern New South Wales (Adkins et al. 1996). In India, it first appeared accidentally in the Indian Botanical Garden, Calcutta during 1810-1814 (Sharma and Pandey 1984). However, it was first observed in Pune and Maharashtra in the mid 1950s (Rao 1956), and now considered as one of the most feared noxious weed species. Ragweed parthenium was reported to infest more than two million ha in India in 1991 and during the last 10 years, it has spread alarmingly to the every parts of the Indian territory except the higher altitude $(>4500 \mathrm{~m})$, invading vast areas of waste and cultivated lands (Aneja et al. 1991, Annapurna and Singh 2003, Kohli and Rani 1994). Because of the transportation system, other than its natural dispersal mechanism it now infests up to mid Himayalayas and even in the dry parts of the northwest India. In Nepal, it was first reported in 1982 by Hara et al. (1982). It is suspected that
Parthenium was introduced in Nepal via India in early 1980 's and has spread rapidly along roadsides, fallow lands and agricultural lands (Tiwari et al. 2005). The introduction of Parthenium hysterophorus to eastern Ethiopia is believed to have occurred along with army vehicles during the Ethiopian-Somalian war of 1976-77, where it has now considered as a one of the most troublesome weeds for grazing and crop land (Tamado and Milberg 2000). Other than those it was also reported from Israel (Joel and Liston 1986) and Taiwan (Peng et al. 1988).

\section{Weed status}

The weed parthenium causes serious problem in every sphere of human life by several ways. The weed is considered as noxious weed due to its prolific seed production, fast spreading ability, potential allelopathic effects on other plant, strong competitiveness with crops, higher phenotypic plasticity and health hazard to humans as well as animals. It is a noxious weed under non cropped situations, but it is becoming a curse by overtaking social forestry, local pastures and any open spaces including residential areas (Singh et al. 2004). It threatens human and animal health by causing allergic contact dermatitis, rhinitis, hay fever, and respiratory problems in sensitive humans and animals. The initial symptoms in human were described as itching, redness, swelling and blisters on the eyelids, face and neck, which then spread to the elbows and knees. In the later stages the skin thickens and darkens (Evans 1997). The reports from the different parts of the world indicated that the weed has larger impact on human welfare than originally supposed. An intensive research from Australia revealed that $10 \%$ to $20 \%$ human population developed severe allergenic reaction after they exposed to the weed for 1 to 10 years period (McFadyen 1995). The weed may cause toxicity; sometimes even death when consumed by animals. The weed reduces the carrying capacity of 
the grazing land significantly and adversely affects animal health, milk and meet quality, marketing of pasture seed and grain. The taste of the milk becomes bitter due to the presence of parthenin, which is hepatoxic (Kohli and Rani 1994). In Australia the weed mainly occurs in Queensland, infesting $170,000 \mathrm{~km}^{2}$ of grazing land and causing $\$ 16.5$ million/year loss to the pasture industry. After considering the expenditure on research into parthenium control particularly in biocontrol it increased up to $\$ 350,000$ during $1990-91$ (Chippendale and Panetta 1994).

Initially, the weed confined to roadside, railway track, wasteland and non-cropped areas, but it started colonizing cropping field very rapidly. In India it was reported that ragweed parthenium has moved from road side to adjoining fields of sugarcane, rice and vegetables crops (Singh et al. 2004). The presence of parthenium in cultivated land can almost double the cultivation costs and restricts the sale and movement of contaminated produce. The weed can reduce yield by $40 \%$ in agricultural crops and up to $90 \%$ in forage production in Indian grassland (Khosla and Sobti 1981, Mahadevappa et al. 2001). The research conducted at Ethiopia showed that in uncontrolled plot parthenium reduces sorghum grain yield up to $40 \%$ to $90 \%$. The overall impact of this weed to agricultural production system is multifaceted and very difficult to quantify the exact amount of loss. Other than those direct effects, the weed aiso damage environment by changing the existing biodiversity. The fast spread of this weed is a matter of serious concern because they are spreading at the exclusion of native plant and changing the plant species composition by reducing natural plant wealth and biodiversity (Batish et al. 2004). So, serious efforts have been initiated in parthenium infested areas of the world to save the natural vegetation and biodiversity by proper management techniques.

\section{Habitat}

Ragweed parthenium can grow over a wide range of temperature and moisture conditions. A number of strategies such as fast growth rate, quick regenerative and reproductive potential, greater stress adaptability, genetic plasticity and lack of natural enemies favor their invasiveness in alien environment (Batish et al. 2004). This weed can rely on phenotypically varying plant traits to exploit the available "invasion windows" (Annapurna and Singh 2003). Ragweed parthenium is primarily found in the wastelands, vacant areas, community parks, roadsides and even invades agricultural fields. Report from Australia showed that it grows best on alkaline, clay loam to heavy black clay soils but tolerates a wide variety of soil type. On the other hand, different opinion found from other reports, where higher clay content $(>3 \%)$ reduced the germination of parthenium seeds and the growth of the plant (Annapurna and Singh 2003).

The arid conditions may reduce its performance and invasiveness by reducing both net photosynthesis and water economy and thus restrict this species to invade arid areas of India and elsewhere (Pandey et al. 2003). Parthenium weed is best suited with an annual rainfall greater than $500 \mathrm{~mm}$. The distribution may be limited by even brief exposure to high day temperature $\left(>40^{\circ}\right)$ or by prolonged drought (Williams and Groves 1980). The low winter temperature considerably reduces growth, flowering and seed production of ragweed parthenium but the established plant can survive at least one mild frost of $-2^{0} \mathrm{C}$. Shading is another important limitation and the weed does not usually become established in undisturbed vegetation or vigorous pasture. It aggressively colonies in areas with poor ground cover, exposed soils such as wastelands, roadside and pastures. Flooded country is also very prone to parthenium weed distribution (Chippendale and Panetta 1994). 
In Ethiopia $90 \%$ lowland farmers and $28 \%$ midland farmers considered parthenium as a most troublesome weed both in crop land and grazing areas. While, the highland farmers only considered as a roadside weed (Tamado and Milberg 2000). But with the experience of Indian subcontinent we can believe that it has the potential to become a serious weed on arable land even in the highland.

\section{Biology}

Parthenium weed is a fast maturing annual herb with a deep tap root and an erect stem that becomes woody with age. It is usually much branched, up to about $1 \mathrm{~m}$ tall but eventually reaches a height of $2 \mathrm{~m}$ at favorable environment. The stem is glabrous or sometimes spreading hirsute below, puberulent or glandular puberulant above. Leaves are pinnatified or usually bipinnatified, pale green and covered with soft fine hairs. The small white flowers have five distinct corners and grow on the stem tips. Each flower produces four to five black wedge shaped seeds that are $2 \mathrm{~mm}$ long with thin white scale. It has a large and persistent soil seed bank and fast germination rate and its dormancy mechanism makes it well adapted to wide range of environments. It also releases chemicals that inhibit the germination and growth of pasture grasses and other plants.

\section{Germination and longevity of seed}

Parthenium weed normally germinates in spring and early summer, produces flowers and seeds throughout its short life and dies in late autumn. Parthenium seeds can germinate well over a wide range of fluctuating temperatures between $12 / 2^{\circ} \mathrm{C}$ to $35 / 25^{\circ} \mathrm{C}$ (Tamado et al. 2002). The temperatures higher than $35^{\circ} \mathrm{C}$ or lower than $5^{\circ} \mathrm{C}$ limit germination of the species and if temperature differential increases from $5^{\circ} \mathrm{C}$ to $11^{\circ} \mathrm{C}$ at low mean temperature then it causes significant reduction of parthenium seed germination (William and Groves 1980). It is well established that germination decreases with decreasing osmotic potential and the effect of moisture stress is more under higher temperature. Germination of seed generally more under $10 \mathrm{~h}$ diurnal photoperiod and it reduces under continuous light and minimum under continuous dark conditions (Pandey and Dubey 1988). But generally this species can germinate under continuous light and continuous dark situations and most freshly harvested parthenium seeds do not have a specific photoperiod requirement for germination (Navie et al. 1998).

Parthenium seeds generally require 30 to 60 days from approximate date of seed dispersal to start emergence in the field and shallow burial $(0.5$ $\mathrm{cm}$ ) gives higher emergence percentage. But seed burial to a depth of $7 \mathrm{~cm}$ or more can temporary prevent seedling emergence (Tamado et al. 2002, Navie et al. 1998). The delay in emergence may be due to the need for after ripening to lower dormancy levels or the need for sufficient moisture to start germination. There is some initial inhibition of germination in freshly shed parthenium seeds and that innate dormancy act in several ways to increase persistence of seeds in fields (Navie et al. 1998). It has been reported that water-soluble germination inhibitors (parthenin and phenolic acids) are present in the accessory structures and seed coat of Parthenium hysterophorus. Emergence of seedling from surface sown seeds may cease quickly, but buried seeds may remain viable in the soil for longer period. The germinability of parthenium seeds decreases with time and can remain viable after being buried for at least 4-6 years (Navie et al. 1998). Parthenin may also increase seed survival by discouraging decay or predation of seeds (Ganeshan and Jayachandra 1993). Generally, larger size seeds give higher germination percentage compare to the smaller ones (Pandey 
and Dubey 1988). But lighter seeds are more dispersible compare to heavier seeds and

parthenium grow on coarse textured soil produces numerous light seeds which facilitate colonization of new sites (Annapurna and Singh 2003). Overall parthenium seeds have a viability of $85 \%$ or more under suitable condition which allow this species to invade and persist in varied ecological and topographical conditions.

\section{Growth and reproduction}

In suitable environment (rain, available moisture, mild soil and air temperature) parthenium can grow and produce any time of the year and four or more successive generation can emerge at the same site during a good growing season (Pandey and Dubey 1989). At early stages of growth it exists as a rosette and then stem elongates rapidly and branching at the apex. The radial leaves spread very close to the ground and encroaching on the whole area and preventing other seedlings to grow which gives a competitive advantage over other species (Kumari and Kohli 1987). Long tap root system with higher amount of energy reserve, favors parthenium to obtain water from deeper layer within soil profile and allow rapid regrowth after the plant is slashed or grazed (Navie et al. 1996). Report from the different parts of the world suggests that ragweed parthenium grows vigorously during summer months compared with winter months. Plants that emerge in the spring time attain a greater plant size and have a longer plant life span. Plant dry matter production increases with increasing temperature up to $33 / 28^{\circ} \mathrm{C}$ and temperature is major factor controlling the length of the vegetative phase (Williams and Grooves 1980). Low winter temperature considerably reduces growth performance, flowering and seed production and photosynthesis of ragweed parthenium by reducing LAI, RGR, NAR, CGR and LAD (Williams and Grooves 1980, Navie et al. 1996, Pandey et al.
2003). Although both high and low temperature have a detrimental effects on growth of parthenium but rate of net photosynthesis decreases more under higher temperature $\left(47^{\circ} \mathrm{C}\right)$. Ragweed parthenium exhibits maximum net photosynthesis rate between 25 to $35^{\circ} \mathrm{C}$ and higher $\mathrm{CO}_{2}$ level also induces higher biomass production (Pandey et al. 2003).

Limited earlier investigations suggest that parthenium has both $\mathrm{C}_{3}$ and $\mathrm{C}_{4}$ photosynthetic pathway with leaves on top having $\mathrm{C}_{3}$ mesophyll with non-Kranz leaf anatomy and leaves at the middle and base having $\mathrm{C}_{4}$ mesophyll with Kranz anatomy (Rajendrudu and Rama Das 1990). However, Pandey et al. (2003) noted that photosynthetic characteristics of parthenium leaf mostly related with $\mathrm{C}_{3}$ type pathway. They also found that stomatal conductance of parthenium is insensitive to photosynthetic photon flux but is greatly influenced by relative humidity. Parthenium flowers earlier with $13 \mathrm{~h}$ day length and generally all flowers come within 103 days (William and Groves 1980). Lewis et al.(1988) found that the time from the first flower bud initiation to the production of mature inflorescence and dispersal of the first achene of parthenium to be about 30 days, while the time from pollination to achene maturation is only about 14 days. There are conflicting reports about the process of pollination of ragweed parthenium. In North American population the insect visit to parthenium weed is rare and wind is major means of pollen dispersal but mechanism of wind pollination is less developed in parthenium compare to other wind pollinated plant (Lewis et al. 1991). On the other hand, Gupta and Chanda (1991) reported that parthenium weed appears to be entomophilous (insect pollinated) or at most amphiphilous (pollen dispersal mainly by insects and partially by wind). Parthenium weed is a prolific seed producer. Joshi (1991) estimated that a single parthenium can produce 25,000 achenes and parthenium weed seed 
bank in the soil to be about $200000 \mathrm{~m}^{-2}$ in abandoned fields in India. Pandey and Dubey (1988) reported achene polymorphism in parthenium weed and they stated that varying climatic conditions in different latitudes governed frequency of the various achene polymorphs. Parthenium weed seeds are capable of being transported in long distances and achenes are transported on motor vehicles or machinery, on livestock, with crop and pasture seed, or in fodder. So, new infestation and spread may appear thousands of kilometers from the original source (Navie et al. 1996).

\section{Allelopathy}

The invasiveness and rapid spread of parthenium have been attributed to its allelopathic effects on other plants. Several workers have demonstrated the allelopathic nature of parthenium. The root and shoot extracts of parthenium inhibit germination and growth of sensitive plant species and these growth inhibitors are released from ragweed parthenium to the soil through leaching, root exudation and residue decay (Mersie and Singh 1988). Sesquiterpene lactones and phenolics are major water soluble allelochemicals present in this plant. Rajan (1973) and Kanchan (1975) first reported the presence of allelochemicals in parthenium weed. In last three decades several types of phenolic and sesquiterpene lactone compounds have been isolated from the roots, stems, leaves, inflorescence, pollen and seeds of ragweed parthenium. The phenolic compounds identified in this plant are caffeic acid, vanillic acid, p-coumaric acid, ferulic acid, anisic acid and clorogenic acid. Parthenium is a rich source of two pseudoguaianolides namely parthenin and coronopilin in addition to some minor constituents like $2 \beta$-hydroxy coronopilin, tetraneurin $\mathrm{A}$, hysterones A-D etc. Venkataiah et al.(2003) recently isolated charminarone, a seco- pseudoguaianolide from parthenium. Parthenium leaves and inflorescence contain highest amount of parthenin followed by the stem and roots successively, while total phenolics were highest in leaves followed by inflorescence, roots and stem successively. Experiment showed that the leaf and flower powder were lethal at relatively lower concentration, and stem residue was lethal at double dose. Singh et al. (2003) demonstrated that extracts prepared from both unburnt and burnt residue of parthenium reduced seedling length and dry weight of radish and chickpea and although burnt residue extracts were found to be more phytotoxic than those from unburnt residue, the amount of phenolics was significantly higher in unburnt residue. Pandey (1994) stated that parthenium plant residue was relatively more toxic to aquatic weeds than to test crop species (wheat and paddy).

Table 1.Various types of allelochemicals identified in Parthenium hysterophorus plants.

\begin{tabular}{lll}
\hline Group & 'Allelochemicals & References \\
\hline Phenolics & $\begin{array}{l}\text { Caffeic, Vanilic, P- } \\
\text { coumaric, Anisic, }\end{array}$ & $\begin{array}{l}\text { (Mersie and } \\
\text { Singh 1988) }\end{array}$ \\
& $\begin{array}{l}\text { Ferulic and } \\
\text { Chlorogenic acids }\end{array}$ & Rajan (1973) \\
Sesquiterpenes & $\begin{array}{l}\text { Parthenin, } \\
\text { Coronopilin, 2- } \beta\end{array}$ & Ramesh et \\
& al. (2003) \\
& Hydroxy & \\
& coronopilin, & \\
& Tetraneurine A, & \\
& hysterones A-D & \\
Seco- & Charminarone & Venkataiah \\
Pseudoguinaloides & & et al. (2003) \\
\hline
\end{tabular}

${ }^{1}$ Compiled by the authors 2006

Residue of parthenium flowers and leaves were found lethal to several aquatic weeds such as water hyacinth (Pandey et al. 1993), salvinia (Pandey 1994), Najas (Pandey 1997) etc. Srivastava et al. 
(1985) discovered that aqueous extracts of parthenium leaves and inflorescence inhibited the germination and seedling growth of barley. Parthenium leachate and organic extract strongly inhibited seed germination and subsequent growth of Brassica campestris seedlings, accompanied by severe reductions in cell survival and chlorophyll content (Kohli et al. 1985). Allelochemicals from ragweed parthenium could be released through two possible mechanisms: Either it produced by microorganism during residue decomposition or they were leached directly from residue (Mersie and Singh 1988). Sarma (1985) found that shoot and litter extracts of parthenium inhibited growth of Rhizobium in laboratory culture. Kanchan and Jayachandra (1981) also showed similar effects of parthenium leachates on nitrogen fixing and nitrifying bacteria. Several researchers demonstrated the mode of action of parthenium allelochemicals. Singh et al. (2002) found that parthenin exerted an adverse effect on protein and carbohydrate metabolism of Ageratum conyzoides. Pandey (1996) reported that parthenin resulted in several physiological changes in water hyacinth, such as damage to cellular membranes loss of dehydrogenase activity in roots and loss of chlorophyll in the leaves.

Parthenin treated plants showed poor cell survival, lower chlorophyll content and lower water retention which inhibited plant regeneration (Kohli et al. 1985). Pandey (1994) observed massive loss of membrane integrity of salvinia due to parthenium allelochemicals. The uptake of nutrients also inhibits by parthenium. Mersie and Singh, (1988) found that iron and zinc content of tomato plant reduced by caffeic, vanillic and ferulic acids which are the major phenolics of parthenium extracts. Several other crops and plants such as cowpea, sunflower, casuarina, acacia, eucalyptus, leucaena, sorghum, maize, ragi soybeans, french beans, cotton, spinach, okra, chilli peppers, clover, mulberry and different Indian and Australian forage crops and grasses showed similar response to parthenium extracts (Evans 1997). The water soluble leachate of ragweed parthenium contains autotoxic components. Kumari and Kohli, (1987) found that parthenium treated with aqueous leachate from leaves and inflorescence showed decrease in chlorophyll content as well as cell survival. But possible explanation for this plant's survival in natural system is either due to the slow release of allelochemicals with less concentration in system or the chemicals do not persist in soil for a long time to affect the system. So it is well documented that parthenium allelochemicals have vast impact on species composition and plant diversity in parthenium infested environments.

\section{Management}

The development of proper control or management strategy to reduce the spread and infestation of ragweed parthenium is major concern in India and Australia. The control of this weed is rather difficult, primarily due to its epidemic spread and strong reproductive and regenerative potential, apart from its wide range of habitat (Kohli et al. 1998). Manual and mechanical methods such as grading, slashing and plowing for controlling ragweed parthenium are not effective (Muniappa et al. 1980, Haseler 1976). Manual cuttings like mowing or slashing results in rapid regeneration of plants followed by flowering and abundant seed production (Dhawan and Dhawan 1996). Although hand pulling of ragweed parthenium is commonly practiced in India, but it involves severe risks as it causes serious health hazards. Without proper disposal method, hand weeding is an ineffective alternative (Navie et al. 1996). Clean cultivation is another option to prevent parthenium seed spread and its infestation. 
Movement of cattle, machinery, vehicle, soil, water and feed from infested area to clean area should be restricted as a preventive measure. Proper legislation such as quarantine law between states and countries of infested and non infested areas is also very effective. Fire after heavy rain also results beneficial as it kills newly germinated parthenium plants but it gives only a short term control (Holman 1981). In Ethiopia, parthenium is currently controlled mainly by hand hoeing and hand pulling. In an experiment, Tamado and Milberg (2004) found repeated hand hoeing as a most effective control measure in grain sorghum compared with 2,4-D application and intercropping with smother crop(cowpea). But hoeing by hand involves huge amount of physical efforts and time. Several researchers reported effective chemical and biological control of parthenium weed in India and Australia. Recently, scientists and extension workers are more concerned to develop suitable integrated management strategy, involving various methods of weed control for parthenium management.

\section{Chemical control}

Successful chemical control of ragweed parthenium has been achieved by different workers. For proper chemical control, selection of herbicide, rate of herbicide and the growth stages of ragweed parthenium are very important factors. Sometimes, after effective application of herbicides the weed will appear from the soil seed bank (Navie et al. 1996). Residual herbicides help to overcome this problem but modern restriction of using herbicide with higher residual activity prevents its application. In cropping situation chemical control is very effective, but where parthenium weed covers a large area, chemical control is not a viable option (Parsons and Cuthbertson 1992). Different experiments showed that ragweed parthenium is susceptible to various herbicides when these are applied at high volume.
In pasture, parthenium can be controlled by 2,4-D $\left(4 \mathrm{~kg}\right.$ ai. ha $\left.{ }^{-1}\right)$, picloram $\left(0.8 \mathrm{~kg}\right.$ ai. ha $\left.{ }^{-1}\right)$, dicamba $\left(1 \mathrm{~kg}\right.$ ai. ha $\left.\mathrm{h}^{-1}\right)$, diuron $\left(2 \mathrm{~kg}\right.$ ai. ha $\left.{ }^{-1}\right)$, karbutilate (1 $\mathrm{kg}$ ai. $\left.\mathrm{ha}^{-1}\right)$, and atrazine $\left(3 \mathrm{~kg}\right.$ ai. ha $\left.{ }^{-1}\right)$ (Haseler 1976). The application of 2, 4-D and atrazine mixture is recommended for effective control as atrazine provides long term residual activity. Singh et al. (2004) found that atrazine plus 2,4-D at 0.5 plus $0.5 \mathrm{~kg} \mathrm{ha}^{-1}$ caused $45 \%$ mortality to ragweed parthenium. Similar author reported that glyphosate formulation MON 8793 and 8794 at 3.6 $\mathrm{kg}$ ae $\mathrm{ha}^{-1}$ provided good control of ragweed parthenium and there was no recovery up to 18 weeks after treatment. Increased efficacy of herbicides is achieved when applied to younger than older plants. Chloromuron at $0.03 \mathrm{~kg} \mathrm{ha}^{-1}$ and metsulfuron at $3.5 \mathrm{~g} \mathrm{ha}^{-1}$ also provided excellent parthenium control when applied to $30 \mathrm{~cm}$ tall plants (Mishra and Bhan 1995). Atrazine with non ionic surfactant can be spot treated in grain sorghum (Parsons and Cuthbertson 1992).

Preemergence application of atrazine $(1.5 \mathrm{~kg}$ ai. ha $\left.{ }^{-1}\right)$, chlorobromuron (1 $\mathrm{kg}$ ai. $\left.\mathrm{ha}^{-1}\right)$ and monuron $\left(0.75 \mathrm{~kg}\right.$ ai. ha $\left.{ }^{-1}\right)$ gave effective control of parthenium in maize and sorghum (Dutta et al. 1976). Same author reported that post-emergence application of DSMA (2 kg ai. ha $\left.{ }^{-1}\right)$ in maize and cowpea and 2,4-D amine ( $2 \mathrm{~kg}$ ai. ha $\left.^{-1}\right)$ in sorghum and maize also controlled parthenium efficiently. In orchard, diquat was found very effective to control this weed without affecting fruit trees (Gupta and Sharma 1977). Parthenium weed also can be controlled by metribuzin in potato and tomato, by terbacil in watermelon and by bromacil and diuron in grapes, pineapple and citrus orchard (Navie et al. 1996). Parthenium weed is also susceptible to many of the other herbicides such as pendimethalin, oxadiazone, imazapyr, oxyfluorfen and thiobencarb (Parsons and Cuthbertson 1992). On the other hand, parthenium weed is not controlled by several other herbicides such as paraquat (Njoroge 1991), trifluralin, diphenamid, napropamide, alachlor, metalachlor and propachlor 
(Labrada 1990). It was also noted that if parthenium was treated repeatedly with paraquat, it became a predominant species within one year in citrus, coffee and banana plantations. The apparent resistance of parthenium to different herbicides generated the need to use herbicidal mixtures or sequence of herbicides against this weed. Knowledge of economical threshold level of parthenium in affected crop is also very useful to determine the proper chemical treatment and it's time of application.

\section{Biological control}

The need of alternative management practices developed as several physical and chemical methods have proved ineffective, uneconomical and environmentally unsafe. Natural suppression of parthenium by biological agents in its native range compared to its increased fitness or vigour in alien environment without natural enemy generated the idea of biological control as a suitable alternative for long term parthenium control. Queensland Department of Lands (QDL), IICB and Commonwelth Institue of Biological Control (CIBC) conducted an entomological survey and screening of selected arthopods in the neotropical centre of origin (Brazil, Argentina and Mexico) of ragweed parthenium (Evans 1997). This results have been reviewed by McClay (1985) and McFadyen(1985). The complete results of North American survey were summarized by McClay et al. (1995), and Navie et al. (1996) listed all insects introduced in Australia with details. Out of 260 phytophagous arthopod species collected from parthenium, only 144 species fed on the plant. Most of these are only occasional feeders and have little detrimental effects on plant (McClay 1981).

Biological control of parthenium was initiated in Australia in 1977 and since then, nine species of insects and one rust fungus have been introduced (McFadyen 1992, 2000, Dhileepan 2001). Among these, the stem galling moth Epiblema strenuana (Walker) (Totricidae), a defoliating beetle Zygogramma bicolorata (Pallister) (Chrysomelidae), a stem boring weevil Listronotus

ECOPRINT VOL 14, 2007 setosipennis (Hustache) (Curculionidae), a seed feeding weevil Smicronyx lutulentus (Dietz) (Curculionidae), a leaf mining moth Bucculatrix parthenica (Bradley) (Bucculatricidae), a stem galling weevil Conotrachilus albocinereus (Fiedler) (Curculionidae) and the winter rust Puccinia abrupta var. partheniicola (Jackson) (Parmelee) are known to be established in the field situation (McFadyen 1992,2000, Dhileepan 2001). The successful control of parthenium was achieved by leaf feeding beetle Zygograma bicolorata (Pallister) and by Stem galling moth Epiblema strenuana (Walker).

Table 2.Herbicides registered in Australia for parthenium control under different situations.

\begin{tabular}{|c|c|c|}
\hline Use & Herbicide & $\begin{array}{c}\text { Rates } \\
\text { (g or kg) }\end{array}$ \\
\hline Non & Atrazine & $4 \mathrm{~kg}$ \\
\hline \multirow[t]{5}{*}{ agricultural } & Atrazin $+2,4-D$ & $1.8-3.2 \mathrm{~kg}+0.4-1 \mathrm{~kg}$ \\
\hline & Dicamba & $300 \mathrm{~g}$ \\
\hline & Hexazinone & $875 \mathrm{~g}$ \\
\hline & Metsulfuron & $3-4.2 \mathrm{~g}$ \\
\hline & Picloram+2,4-D & $225 g+900 g$ \\
\hline \multirow{5}{*}{$\begin{array}{l}\text { Fields and } \\
\text { fallow }\end{array}$} & Atrazine & $1.8-3.2 \mathrm{~kg}$ \\
\hline & Atrazine $+2,4-\mathrm{D}$ & $1.8-3.2 \mathrm{~kg}+0.4-1 \mathrm{~kg}$ \\
\hline & Dicamba & $160-280 \mathrm{~g}$ \\
\hline & Picloram + 2,4-D & $75 g+300 g$ \\
\hline & $\begin{array}{l}\text { Glyphosate + } \\
\text { metsulfuron }\end{array}$ & $290-430 \mathrm{~g}+3-4.2 \mathrm{~g}$ \\
\hline \multirow[t]{4}{*}{ Pastures } & Hexazinone & $875 \mathrm{~g}$ \\
\hline & Metsulfuron & $3-4.2 \mathrm{~g}$ \\
\hline & Picloram + 2,4-D & $225 g+900 g$ \\
\hline & 2,4-D amine & $200 \mathrm{~g}$ \\
\hline Broom millet & Atrazine & $1.2-3.2 \mathrm{~kg}$ \\
\hline $\begin{array}{l}\text { Forage } \\
\text { sorghum }\end{array}$ & Atrazine & $1.2-3.2 \mathrm{~kg}$ \\
\hline \multirow[t]{3}{*}{ Maize } & Atrazine & $2.2-3.2 \mathrm{~kg}$ \\
\hline & Dicamba & $160-280 \mathrm{~g}$ \\
\hline & Picloram + 2,4-D & $75 g+300 g$ \\
\hline \multirow[t]{3}{*}{ Sorghum } & Atrazine & $2.2-3.2 \mathrm{~kg}$ \\
\hline & Dicamba & $160-280 \mathrm{~g}$ \\
\hline & Picloram + 2,4-D & $75 g+300 g$ \\
\hline Sweet corn & Atrazine & $2.2-3.2 \mathrm{~kg}$ \\
\hline
\end{tabular}

Source: Navie et al. 1996 
Dhileepan (2001) reported that Zygograma bicolorata (Pallister) caused $96 \%$ defoliation and Epiblema strenuana (Walker) affected $100 \%$ of the plants, resulting in reductions of $90 \%$ in weed density, $40 \%$ in plant height and $82 \%$ in flower production. The larvae of Listronotus setosipennis (Hustache) exert a significant damage to parthenium weed and when several are present they may kill young plant (Wild et al. 1992). Although, Listronotus weevil showed some feeding development on sunflower, it was later released in Australia between 1982 and 1986. For introduction of biological agent there is scepticism about host specificity and on the background of this faunal relationship of parthenium with other species is very important. There is a high degree of faunus similarity between parthenium and Helianthus $(>8 \%)$ and few pest can damage sunflower also but the risk of field damage is very limited. Moth Epiblema strenuana was found very effective in Australia but erratic rainfall patterns disrupted the moth population and reduced them in very low level. It was also introduced in India but as it attacked another compositae crop, it was withdrawn. In the initial stage, Zygograma beetle was very effective, but later the spread of this bio agent slowed down as this species was unable to adjust to the variable rainfall pattern (Navie et al. 1996). Report showed that defoliation by Zygograma beetle reduced parthenium population up to $99.5 \%$ and parthenium were replaced by 40 different plant species in fallow land (Jayanth and Visalakshy 1996). Stem galling moth Epiblema strenuana damaged the meristem at early growth stage and as a result prevented $32 \%$ of plants from producing any flower (Dhileepan 2001). Another stem-galling weevil, Conotrachelus albocinereus (Fiedler) is also a potential bio-agent as this insect damage parthenium by galling stem tips and auxiliary buds (McFadyen 2000). Similar author reported that stem galling weevil is host-specific and there is minimal risk of damage to any non target plant other than annual ragweed. The larvae of Bucculatrix parthenica eat the leaves of parthenium weeds and in higher abundance it can causes extensive defoilation of host plant (McClay et al. 1990), but the larvae of weevil Smicronyx lutulentus feed on the disc florets and developing achenes of parthenium (McClay et al. 1981). In India, several number of indigenous insects attack parthenium weed but none causes significant damage on vast scale. The proper screening of bioagent with adaptability to wider range of climate is very important characteristic for Indian condition. Earlier Zygograma bicolorata was introduced in India and until now some impact was observed in the Banglore region, India (Navie et al. 1996) but Epiblema strenuana was rejected because of attack on Guizotia abyssinica (McFadyen 1992).

Parthenium is a host of two different pathogenic rust fungi Puccinia abrupta var. parthenicola (Jackson) Parm. and Puccinia melampodii (Diet and Holw.) in Mexico (Navie et al. 1996). It was observed that it occurs and damage parthenium significantly in similar climatic conditions like Queensland and further study on this pathogen was initiated. In UK pathogenicity of rust fungus to parthenium was studied and they found that infection hastened leaf senescence, significantly decreased the life span and dry weight of parthenium plant and reduced flower production by $90 \%$ (Parker et al. 1994, Evans 1997). The pathogen was found highly host-specific and it was released in central Queensland after 1991 (Evans 1997). Significant damage by the rust was observed in field condition in earlier stage but drought and high night time temperature limited its further spread. The rust strain was found more effective when night temperature fell below $20^{\circ} \mathrm{C}$ and preferably around $17^{\circ} \mathrm{C}$ (Parker et al. 1994). Another rust strain Puccinia melampodii and white smut, Entyloma parthenii showed promising as a biocontrol agent in field condition (Evans 1997). 
Some mycoplasma like organism causing serious damage to parthenium plant was noticed in India but a little success was achieved (Navie et al. 1996).For mycoherbicide development, Myrothecium roridum Tode ex Fr. appeared very promising against parthenium In India (Pandey et al. 1992). Most of the evaluated fungi suppressed seed germination and successively caused high seedling mortality of parthenium including Colletotricum gloeosporioides (Penz) Sacc.; Fusarium oxisporum Schlect.; Fusarium monoliforme Sheld and Myrothecium roridum (Evans,1997). Collar rot disease of parthenium by Sclerotium rolfsii Sacc. was reported form India but later screening showed that isolates were pathogenic to number of crop plants, like cabbage, beans, castor and Amaranthus (Mishra et al. 1994).Several research on similar line were carried out in India and Australia but no formulated mycoherbicide has reached for field experiment.

Table 3. Species released as biological control agents of Parthenium hysterophorus and their establishment in Australia.

\begin{tabular}{lcc}
\hline Species & $\begin{array}{c}\text { Country of } \\
\text { origin }\end{array}$ & $\begin{array}{c}\text { First } \\
\text { released }\end{array}$ \\
\hline Coleoptera & Argentina & 1993 \\
$\begin{array}{l}\text { Conotrachelus sp } \\
\text { Listronotus setosipennis }\end{array}$ & $\begin{array}{c}\text { Brazil/ } \\
\text { Argentina }\end{array}$ & 1983 \\
Smicronyx lutulentus & Mexico & 1980 \\
Zygrograma bicolorata & Mexico & 1980 \\
Homoptera & & \\
Stobaera concinna & Mexico & 1983 \\
Lepidoptera & & \\
Bucculatrix parthenica & Mexico & 1984 \\
Epiblema strenuana & Mexico & 1982 \\
Platplhalonidia mystica & Argentina & 1992 \\
\hline
\end{tabular}

Source: White 1994, Navie et al. 1996

The use of natural plant with allelopathic potential is gaining real attention in modern weed

ECOPRINT VOL 14, 2007 control management. Singh (1983) first noticed that Cassia uniflora (Leguminosae) had ability to replace parthenium, in originaly parthenium infested areas. Other Cassia spp. such as $C$. serecea, C. tora, C. auriculata and C. occidentale also has proven allelopathic trees against parthenium (Naithani 1987, Mhadevappa and Ramaiah 1988). Allelopathic leachates of those plants affected germination and growth of parthenium. But the flowers and seeds, which are the main source of dissemination, remain unaffected. The success of Cassia uniflora has not been achieved due to its unsuitability in varying climatic conditions and difficult cultural requirement (Joshi 1991). It was also discovered that C. uniflora is a major host of Bemisia whiteflies, which transmitted leaf curl virus to tomato and other plants (Evans 1997). Kohli and Kumar (1997) investigated effects of three tree species, Eucalyptus tereticornis, Populus deltoides and Leucaena leucocephala on parthenium and observed poor growth of parthenium under those plantations. The greatest effects were observed under Eucalyptus tereticornis, followed by Leucaena leucocephala and Populus deltoides. Kohli et al.(1998) found that volatile terpenes of Eucalyptus spp. reduced seed germination, chlorophyll content as well as cellular respiration of parthenium. The inhibitory effect of sunflower (Helianthus annus) on parthenium was also observed (Azania et al. 2003).

\section{Future strategy}

The thorough study of ragweed parthenium established its significant role in today's environment. There is no doubt about the potential lethal impact of this weed on human affairs. As this species spreads very rapidly, there is always a possibility of introduction of this species in areas where parthenium is not present until now. If we consider all detrimental effects including, pollen allergy, animal toxicity, agricultural loss, 
biodiversity and allelopathy then it demands a serious effort to develop proper management for the vast parthenium infested areas of Australia, India and Africa. Research efforts both in Australia and India in last three decades resulted several promising management options, but still there is not a single tool, which can eradicate parthenium without affecting surrounding environment.

The First International Conference on Parthenium Management held at Dharwad, Karnataka, India (1977) focused to evaluate overall impact of this weed and probable future directions to solve one of the major problems of modern biological science. Proper assessment of economical losses, biological risks and also benefits is very important as it will help scientists to establish their future research goal about parthenium. The integrated pest management strategy including mechanical, biological and chemical methods can solve this problem in sustainable manner. The identification of effective control measure and evaluation of the compatibility of those techniques with other management option is necessary. The knowledge about the biology, physiology and growth of parthenium aiso help to control this weed in proper stage with less effort.

The mass awareness and community participation is very important to deal this weed problem in both urban and rural situations. Batish et al. (2004) reported that one area in Chandigarh, India, was severely infested with the parthenium weed and residents were scared of even entering the zone with the fear of getting health problems. But after they were educated about the biology and possible threat of the weed, which would aggravate without proper control measure, people started participating in uprooting activity before flowering stage. Such kind of motivation with proper knowledge base can efficiently remove this type of invasive species from a certain locality.
Queensland government in Australia and Karnataka government in India initiated few awareness and extension program to help people for managing this weed without any health problem. Even medical scientists are now very much aware and started several researches to combat pollen allergy of ragweed parthenium. The cheap and plentiful labor market in India can encourage the manual control of this weed, but possible health hazards and without suitable disposal mechanism after removal, does not help this issue with greater extent (Evans 1997). The abundance of this species in fallow, roadside, railway track and other non cropland areas also require serious attention to prevent the spread of this weed. Few potential allelopathic plants can control parthenium in those areas without affecting surrounding environment. Otherwise it is very difficult to control parthenium in such vast areas with chemical or mechanical methods.

The research on biological control program with other alternative strategies is important. The screening of insect, pathogen and study on their climatic adaptability and host specificity can provide a real solution in near future. Development of a mycoherbicide program in addition to the classical approach of biocontrol can minimize the probable adverse effects on environment, which really prevents the use of biological agent in different climatic conditions. If quarantine hurdles can be overcome then introduction of suitable bioagent may resolve this problem. Both in Australia and in India Zygograma bicolorata proved its potential and generated a real hope for future bio-control research. The biological research is still in progress in Australia but it should still be explored in India. The wide climatic variation within Indian subcontinent obviously poses a major problem for biocontrol, however, comprehensive research efforts in various parts of the country can really evaluate the potential benefit of biocontrol agents against parthenium.

ECOPRINT VOL 14, 2007 
The beneficial role or use of parthenium should also consider in time of planning future action. Antitumor and antiamoebiasis activity of parthenin has been reported by different authors (Mew et al. 1982, Sharma and Bhutani 1988). Parthenium was used as a folk medicine in the Caribbean and Central America and also used as a flea repellent in Jamaica (Navie et al. 1996). Partehnium is valuable source of potash, oxalic acid and easily extractable high quality protein that can be used in animal feed (Mane et al. 1986, Savangikar and Joshi 1978).

Our primary concern about this weed is development of suitable management strategies. The formation of parthenium action group including representatives from different sector in problem areas can provide a suitable remedy option. The multidisciplinary research and proper communication or transformation of technology from lab to land is important for eradicating this obnoxious species. Otherwise, it can be a real threat in any parts of the world in next few decades and will become a global menace, comprising more complex characteristics.

\section{REFERENCES}

Adkins, S.W., S.C. Navie and R.E. McFadyen. 1996. Control of Parthenium Weed (Parthenium hysterophorus L.): A centre for Tropical Pest Management Team Effort. 11 th Aust. Weeds Conf., R.C.H. Sheperd (ed.) Weed Sci. Soc. Victoria, Frankston. pp. 573-578.

Aneja, K.R., S.R. Dhawan and A.B. Sharma. 1991. Deadly weed-Parthenium hysterophorus L.and its distribution. Indian J. Weed. Sci. 23:1418.

Annapurna, C. and J.S. Singh. 2003. Phenotypic plasticity and plant invassiveness: Case study of congress grass. Current Sci. 85(2):197-201.

Azania, A.A.P.M., C.A.M. Azania, P.L.C.A. Alves, R. Palaniraj, H.S. Kodian, S.C. Sati, L.S. Rawat, D.S. Dahiya and S.S. Narwal.
2003. Allelopathic plants 7. Sunflower (Helianthus annuus L.). Allelopathy Journal. 11(1):1-20.

Baily, L.H. 1960. Manual of Cultivated Plants. Macmilla, New York.

Batish, R.D., H.P. Singh, K.R. Kohli, V. Johar and S. Yadav. 2004. Management of Invasive Exotic Weeds Requires Community Participation. Weed Technology. 18:14451448.

Bhowmik, P.C. and D. Sarkar. 2005. Parthenium hysterophorus: Its world status and potential management. Proceedings Second International Conference on Parthenium Management. Univ. Agric. Sciences, Bangalore, India. pp. 1-5.

Chippendale, J.F. and F.D. Panetta. 1994. The cost of parthenium weed to the Queensland cattle industry. Plant Protection Quarterly. 9:73-76.

Dhawan, S.R. and P. Dhawan. 1996. Regeneration in Parthenium hysterophorus L. World Weed. 3:181-182.

Dhileepan, K. 2001. Effectiveness of introduced biocontrol insects on the weed Parthenium hysterophorus (Asteraceae) in Australia. Bulletin of Entomological Research. 91:167176.

Dutta, T.R., J.N. Gupta and S.R. Gupta. 1976. Preand post-emergence control of Parthenium hysterophorus Linn. Science and Culture. 42:179-181.

Evans, H.C. 1997. Parthenium hysterophorus: a review of its weed status and possibilities for biological control. Biocontrol News and Information. 18(3):89-98.

Ganeshan, G. and Jayachandra 1993. Antifungal activity of parthenin. Indian Phytopathology. 46:193-194.

Gleason, H.A. and A. Cronquist. 1963. Manual of Vascular Plants of Northeastern United States 
and Adjacent Canada. D Van Nostrand Company, New York, USA. 691 pp.

Gupta, O.P. and J.J. Sharma. 1977. Parthenium menace in India and possible control measures. FAO Plant Protection Bulletin. pp. 112-117.

Gupta, S. and S. Chanda. 1991. Aerobiology and some chemical parameters of Parthenium hysterophorus pollen. Grana. 30:497-503.

Hara , H., A.O. Chater and L.H.J. Williams. 1982. An Enumeration of The Flowering Plants of Nepal. Vol. III. Trustee of British Museum (Natural History), London. 3:35.

Haseler, W.H. 1976. Parthenium hysterophorus L. In Australia PANS. 22:515-517.

Holman, D.J. 1981. Parthenium weed threatens Bowen Shire. Queensland Agricultural Journal. 107:57-60.

Jayanth, K.P. and P.N.G. Visalakshy. 1996. Succession of vegetation after suppression of parthenium weed by Zygograma bicolorata in Banglore, India, Biological Agriculture and Horticulture. 4:363-365.

Joel, D.M. and A. Liston. 1986. New adventive weeds in Israel. Israel Journal of Botany. 35:215-223.

Joshi, S. 1991. Biocontrol of Parthenium hysterophorus L. Crop Protection. 10:429-431.

Kanchan, S.D. 1975. Growth inhibitors from Parthenium hysterophorus Linn. Current Science. 44:358-359.

Kanchan, S.D. and Jayachandra. 1981. Effect of Parthenium hysterophorus on nitrogen-fixing and nitrifying bacteria. Canadian Journal of Botany. 59:199-202.

Khosla, S.N. and S.N. Sobti. 1981. Effective control of Parthenium hysterophorus L. Pesticides. 15:18-19.

Kohli, R.K and S. Kumar. 1997. Control of Parthenium hysterophorus L through allelochemicals from a few multipurpose exotic trees. First International Conference on Parthenium Management, Dharwad, India, 6-8 October 1997 University of Agricultural Sciences. 37-39.

Kohli, R.K. and Daizy Rani. 1994. Parthenium hysterophorus- A Review. Research Bulletin of the Punjab University (Science) 44(I-IV):105149.

Kohli, R.K., R.D. Batish and H.P. Singh. 1998. Eucalyptus oils for the control of parthenium (Parthenium hysterophorus L.) Crop Prot. 17:119-122.

Kohli, R.K., A. Kumari and D.B. Saxena. 1985. Auto-and teletoxicity of Parthenium hysterophorus L. Acta Universitatis Agriculturae Brno [Czechoslovakia] 33:253263.

Kumari, A. and R.K. Kohli. 1987. Autotoxicity of Ragweed Parthenium (Parthenium hysterophorus). Weed Sci. 35:629-632.

Labrada, R. 1990. El manejo de malezas en areas de hortalizas y frizol en Cuba. X ALAM, La Habana, abril. 1-14, vol-II:1-16

Lewis, W.H., A.B. Dixit and H.J. Wender. 1988. Reproductive biology of Parthenium hysterophorus (Asteraceae). Journal of Palynology. 23-24:73-82.

Lewis, W.H., A.B. Dixit and H.J. Wender. 1991. Asteraceae aeropollen of the western United States Gulf Coast. Annals of Allergy. 67:37-46.

Mahadevappa, M. and H. Ramaiah. 1988. Pattern of replacement of Parthenium hysterophorus plants by Cassia sericea in waste lands. Ind. J. Weed Sci. 20:83-85.

Mahadevappa, M., T.K. Das and A. Kumar. 2001. Parthenium: Acurse for natural herbs. In: Proceedings of National Research Seminar on Herbal Conservation, Culture, Marketing and Utilization with Special Emphasis on

ECOPRINT VOL 14, 2007 
Chhatisgarh- "The Herbal State", Raipur, India, December 13-14, 2001. Chhatisgarh, India: Srishti Herbal Academy and Research Institute. pp. 13.

Mane, J.D., S.J. Jadhav and N.A. Ramaiah. 1986. Production of oxalic acid from dry powder of Parthenium hysterophorus L. Journal of Agriculture and Food Chemistry. 34:989-990.

McClay, A.S. 1985. Biocontrol agents for Parthenium hysterophorus from Mexico. In: Proceedings of the $6^{\text {th }}$ International Symposium on Biological Control of Weeds, Vancouvar, Canada, August 1984. (ed.). E.S. Delfosse. Ottawa, Canada, Agriculture Canada. 771-778.

McClay, A.S. 1981. Studies of some potential biocontrol agents fro Parthenium hysterophorus in Mexico. Proceedings of the $V$ th International Symposium on the Biological Control of Weeds, Brisbane, Australia. (ed.) E.S. Delfosse. pp. 471-482.

McClay, A.S., R.E. McFadyen and J.D. Bradley. 1990. Biology of Bucculatrix parthenica Bradley sp. n. (Lepidoptera:Buculatricidae. and its establishment in Australia as a biological control agent for Parthenium hysterophorus (Asteraceae). Bulletin of Entomological Research. 80:427-432.

MeClay, A.S., W.A. Palmer, F.D. Bennett and K.R. Pullen. 1995. Phytophagous arthopods associated with Parthenium hysterophorus (Asteraceae. in North America. Environmental Entomology. 24:796-809.

McFadyen, R.E. 1985. The biological control programme against Parthenium hysterophorus in Queensland In: Proceedings of the $6^{\text {th }}$ International Symposium on Biological Control of Weeds, Vancouvar, Canada, August 1984. (ed.) E.S. Delfosse. Ottawa, Canada, Agriculture Canada. pp. 789-796.
McFadyen, R.E. 1992. Biological control against parthenium weed in Australia. Crop Protection. 24:400-407.

McFadyen, R.E. 1995. Parthenium weed and human health in queensland. Australian Family Physician. 24:1455-1459.

McFadyen, R.E. 2000. Biology and host specificity of the stem galling weevil Conotrechelus albocinerus Fielder (Col: Curculionidae), apotential biocontrol agent for parthenium weed Parthenium hysterophorus L. (Asteraceae. in Queensland, Australia, Biocontrol Science and Technology. 10:195200.

Mersie, W. and M. Singh. 1988. Effects of Phenolic Acids and Ragweed Parthenium (Parthenium hysterophorus. Extracts on Tomato (Lycopersicon esculentum. Growth and Nutrient and Chlorophyll Content. Weed Sci. $36: 278-281$.

Mew, D., F. Balza, G.H.N. Towers and I.G. Levy. 1982. Antitumour effects of the sesquiterpene lactone parthenin. Planta Medica. 45:23-27.

Mishra, J., A.K. Pandey, R.C. Rajak and S.K. Hasija. 1994. Microbial management of parthenium-I. Host specificity of Sclerotium rolfsii Sacc. National Academy Science Letters, India. 17:169-173.

Mishra, J.S. and V.M. Bhan. 1995. Efficacy of sulfonylurea herbicides against Parthenium hysterophorus L. Ind. J. Weed Sci. 27:45-48.

Mishra, K.K. 1991. Parthenium hysterophorus L. -a new record for Nepal, J.Bombay Nat. Hist. Soc. 88:466-467.

Muniappa, T.V., T.V.R. Prasad and K. Krishnamurthy. 1980. Comparative efficacy and economics of mechanical and chemical methods of control of Parthenium hysterophorus Linn. Ind. J. Weed Sci. 12:137144. 
Naithani, H.B. 1987. Parthenium hysterophorus -a precious weed in Arunachal Pradesh and Nagaland. Indian Forester. 113:709-710.

Navie, S.C., R.E. McFadyen, F.D. Panetta, and S.W. Adkins. 1996. The biology of Australian weeds 27. Parthenium hysterophorus L. Plant Protection Quarterly. 11:76-88.

Navie, S.C., F.D. Panetta, R.E. McFadyen and S.W. Adkins. 1998. Behaviour of buried and surface-sown seeds of Parthenium hysterophorus. Weed Res. 38:335-341.

Njoroge, J.M. 1991. Tolerance of Bidens pilosa L. and Parthenium hysterophorus L. to paraquat Gramaxone. in Kenya. Kenya Coffee. 56:9991001.

Pandey, A.K., B.M. Luka, S.K. Hasija and R.C. Rajak. 1992. Evaluation of Myrothecium roridum for the management of Parthenium hysterophorus: inoculum rate studies. Proceedings of the National Academy of Science, India. 62:449-453.

Pandey, D.K. 1994. Inhibition of Salvinia (Salvinia molesta Mitchell. by Parthenium (Parthenium hysterophorus L.. II. Relative effect of flower, leaf, stem and root residue on Salvinia and Paddy. J. Chem. Ecol. 20(12):3123-3131.

Pandey, D.K. 1996. Phytotoxicity of sesquiterpene lactone parthenin on aquatic weeds. J. Chem. Ecol. 22:151-160.

Pandey, D.K. 1997. Inhibition of najas (Najas graminea Del.. by parthenium (Parthenium hysterophorus L.). Allelopathy Journal. 4(1):121-126.

Pandey, D.K., L.P. Kauraw and V.M. Bhan. 1993. Inhibitory effect of parthenium (Parthenium hysterophorus L.. residue on growth of water hyacinth (Eichornia crassipes Mart Solms.. II. Relative effect of flower, leaf, stem and root residue. J. Chem. Ecol. 19(11):2663-2670.
Pandey, D.K., L.M.S. Palni and S.C. Joshi. 2003. Growth, reproduction and photosynthesis of ragweed parthenium (Parthenium hysterophorus). Weed Sci. 51:191-201.

Pandey, H.N. and S.K. Dubey. 1988. Achene germination of Parthenium hysterophorus L.: effects of light, temperature, provenanace and achene size. Weed Res. 28:185-190.

Pandey, H.N. and S.K. Dubey. 1989. Growth and population dynamics of an exotic weed Parthenium hysterophorus L. Proceeding of the Indian Academy of Science (Plant Sciences). 99:51-58.

Parker, A., A.N.G. Holden and A.J. Tomley. 1994. Host specificity testing and assessment of the pathogenecity of the rust, Puccinis abrupta var. parthenicola, as a biological control agent of parthenium weed (Parthenium hysterophorus). Plant Pathology. 43:1-16.

Parsons, W.T. and E.G. Cuthbertson. 1992. Noxious Weeds in Australia. Inkata Press, Melbourne, Australia. 692.

Peng, C.I., L.A. Hu and M.T. Kao. 1988. Unwelcome naturalisation of Parthenium Hysterophorus (Asteraceae. in Taiwan. Journal of Taiwan Museum. 41:95-101.

Rajan, L. 1973. Growth inhibitors from Parthenium hysterophorus Linn. Current Science. 42:729-730.

Rajendrudu, G. and V.S. Rama Das. 1990. C3- like carbon isotop discrimination in $\mathrm{C} 3-\mathrm{C} 4$ intermediate Alternenthera and Parthenium species. Curr. Sci. 59:377-379.

Ramesh, C., N. Ravindranath, B. Das, A. Prabhakar, J. Bharatam, K. Ravikumar, A. Kashinatham and T.C. McMorris. 2003. Pseudoguaianolides from flowers of Parthenium hysterophorus. Phytochemistry. 64:841-844. 
Rao, R.S. 1956. Parthenium: A new record for India. J. Bombay Nat. Hist. Soc. 54:218-220.

Sarma, K.K.V. 1985. Effect of Parthenium hysterophorus extract on Rhizobium. Tropical Ecology. 26(1):85-86.

Savangikar, V.A. and R.N. Joshi. 1978. Edible protein from Parthenium hysterophorus. Experimental Agriculture. 14:93-94.

Sharma, G.L. and K.K. Bhutani. 1988. Plant based antiamoebic drugs. Part II. Amoebicidal activity of parthenin isolated from Parthenium hysterophorus . Planta Medica. 54:20-22.

Sharma, B.P. and D.S. Pandey. 1984. Exotic Flora of Allahabad. Botanical Survey of India, Flora of India Series IV.

Singh, H.P., D.R. Batish, R.K. Kohli, D.B. Saxena and V. Arora. 2002. Effect of parthenin-a sesquiterpene lactone from Parthenium hysterophorus - on early growth and physiology of Ageratum conyzoides. J. Chem. Ecol. 28(11):2169-2179.

Singh, H.P., D.R. Batish, J.K. Pandher and R.K. Kohli. 2003. Assesment of allelopathic properties of Parthenium hysterophorus residues. Agricultural, Ecosystem and Environment. 95:537-541.

Singh, N.P. 1983. Potential biological control of Parthenium hysterophorus L. Current Science. $52: 644$.

Singh, S., A. Yadav, R.S. Balyan, R.K. Malik and M. Singh. 2004. Control of Ragweed Parthenium (Parthenium hysterophorus. and Associated Weeds. Weed Technology, 18:658664.

Srivastava, J.N., J.P. Shukla and R.C. Srivastava. 1985. Effect of Parthenium hysterophorus Linn. Extract on the seed germination and seedling growth of barley, pea and wheat. Acta Botanica Indica. 13:194-197.

Tamado, T. and P. Milberg. 2000. Weed flora in arable fields of eastern Ethiopia with emphasis on the occurrence of Parthenium hysterophorus. Weed Res. 40:507-521.

Tamado, T., W. Schutz and P. Milberg. 2002. Germination ecology of the weed Parthenium hysterophorus in eastern Ethiopia. Ann. Appl. Biol. 140:263-270.

Tiwari, S., B. Adhikari, M. Siwakoti and K. Subedi. 2005. An Inventory and Assessment of Invasive Alien Plant Species of Nepal. IUCN Nepal. 115 pp.

Tomado, T. and P. Milberg. 2004. Control of Parthenium (Parthenium hysterophorus. in Grain Sorghum (Sorghum bicolor. in the Small holder Farming System in Eastern Ethiopia. Weed Technology. 18:100-105.

Venkataiah, B., C. Ramesh, N. Ravindranath and B. Das. 2003. Charminarone, a secopseudoguaianolide from Parthenium hysterophorus. Phytochemistry. 63:383-386.

White, G.C. 1994. Workshop Report: Parthenium Weed. Cooperative Research Centre for Tropical Pest Management, Brisbane.

Wild, C.H, R.E. McFadyen, A.J. Tomley and B.W. Wilson. 1992. The biology and host specificity of the stem boring weevil Listronotus setosepennis (Col:Curculionidae. a potential biocontrol agent for Parthenium hysterophorus (Asteraceae. Entomophaga) 37:591-598.

Williams, J.D. and R.H. Groves. 1980. The influence of temperature and photoperiod on growth and development of Parthenium hysterophorus L.Weed Res. 20:47-52. 